\title{
Stimulating Environmental Investments in the "Green" Economy of Eurasia
}

\author{
Nina Kazitskaya ${ }^{1, *}$, Vera Prusova $^{1}$, and Sergey Bochkov ${ }^{1}$ \\ ${ }^{1}$ Moscow Automobile and Road Construction State Technical University (MADI), 125319, 64 \\ Leningradsky av., Moscow, Russia
}

\begin{abstract}
To date, investment in industrial production and infrastructure has passed through a certain bifurcation point associated with the division into "green" (environmental) and traditional (resource and nature-intensive) investments. Following the new demands of modern society to improve the environment and reduce the pressure on it from industry, the concept of traditional economic growth based on extensive environmental management is being replaced by ideas of sustainable development related to resource conservation, waste recycling and reduction of polluting emissions into the biosphere. As a result, investment as the basis of economic growth is also gravitating towards a green economy, participation in which is gradually becoming a major competitive advantage for the markets of developed countries. In this process, the role of the state in stimulating nature-saving investments, in which indirect instruments (subsidies, tax incentives), take an increasing place, is growing many times over.
\end{abstract}

\section{Introduction}

In the last two years, the idea of a "green" economy has become widely discussed not only by experts in environmental economics [1-2], but also in various political forums. It is increasingly mentioned by state representatives, as well as in joint statements and discussed in the context of sustainable development and improving the quality of life [3-4]. Increasing interest in the concept of a "green" economy is facilitated by the growing ecological inefficiency of the economic model of constant growth of production implemented in advanced countries through the involvement of non-renewable resources. Along with this, the instability of environmentally oriented investments, generated by numerous crises and market failures, deprives investors and entrepreneurs of confidence in the profitability of such investments [5-6].

The transition to a green economy has a solid economic and technological rationale. The state and business have convincing arguments in favor of combining efforts aimed at restructuring industry towards resource-saving production and recycling. The government therefore faces the challenge of leveling the playing field for green products by eliminating outdated subsidies, reforming policies and creating new incentives, strengthening market

\footnotetext{
* Corresponding author: $\underline{\text { madi@madi.ru }}$
} 
infrastructure, redirecting public investment and moving towards green public procurement. [7] The challenge for the private sector is to recognize and exploit the genuine opportunities presented by the green economy transition in a number of key sectors, and to respond to policy reforms and price signals by increasing funding and investment. [8]

Over the past decade, mankind has simultaneously experienced several crises: the climate crisis, the crisis of biodiversity, fuel, food, water, and in recent years the crisis of the financial system and the economy as a whole [8]. The increase in emissions that change the atmosphere indicates a growing threat of rapid climate change, which can lead to catastrophic socioeconomic consequences for humanity [9]. Fluctuations in commodity and food prices over the past 20 years indicate structural problems in industrialized countries and associated environmental risks that remain unaddressed. The growth in demand for mineral energy, predicted by the International Energy Agency, implies continued dependence on oil and other fossil fuels and a significant increase in energy prices as the world economy is going through a phase of recovery after the sharp decline caused by the COVID-19 pandemic. [10] All this requires rethinking the mechanisms for investing in the green economy and stimulating this process.

\section{Materials and Methods}

Over the past two decades, the priority non-financial investments have been associated with real estate and the extraction of fossil fuels [11]. Financial assets, in turn, were dominated by financial derivatives [12-13]. At the same time, relatively little funds were allocated by companies and the state for the development of renewable energy and closed production chains for the movement of resources, improving the energy efficiency of the manufacturing industry and transport, along with reducing emissions, for the development of stable agriculture, protecting biodiversity and preserving soil and water resources [14-15]. At the same time, most of the national strategies for economic development stimulated the rapid accumulation of material, financial and human capital, however, due to the excessive depletion of natural capital, since natural resources and ecosystems were relegated to the background [16-17]. Since the world stock of natural resources is being depleted (and the process of depletion is often irreversible), the model of extensive use of natural resources already negatively affects the well-being of present generations and creates huge risks and problems for future generations.

Existing investment mechanisms (including the stock market) and market incentives exacerbate the problem of ecologically unsustainable capital allocation, as firms are allowed to carry out activities that have negative consequences for the environment, often without adequate control [18]. This identifies the need for improved government policies, including pricing and regulatory measures, in order to change the market incentives that drive this misallocation of capital and ignore environmental impacts [19]. The scientific rationale for regulatory instruments that include tax incentives for green investors has the potential to change the private investment model.

In its simplest sense, "green" investing is expanding the funds of a low-carbon industry that uses resources efficiently and thus serves a broad public interest. In a green economy, income and employment growth is driven by public and private investments that reduce carbon emissions and pollution, increase energy and resource efficiency, and prevent the loss of biodiversity and ecosystem services [20-21]. These investments need to be scaled up and sustained through targeted government spending, environmental regulatory reforms, and changes in emissions and recycling standards. [22] This development path should preserve and restore natural capital as the most important source of public goods. Natural resources 
play a special role for the poorest strata of the population, whose incomes and livelihoods depend on nature [23].

\section{Results and Discussion}

The investment regulation system, which takes into account the specifics of resourcesaving technologies and recycling, should create incentives that will intensify the transition to a green economy, as well as remove barriers to its investment. The regulatory system can reduce the most harmful activities that are incompatible with sustainable development, either by setting minimum standards or by completely banning certain activities. In addition, an adequate regulatory framework will reduce the risks of legislative changes and business risks and increase investor confidence in the markets. Companies are often better off dealing with well-defined and truly enforced standards than dealing with uncertainty or unfair competition from those who do not comply with regulatory requirements. Self-regulation of industries and voluntary agreements between government and companies that relieve government agencies from some of the information burden and administrative costs can be a good complement to government rules and regulations. Using public procurement methods, it is possible to generate a high and long-term demand for "green" goods and services.

Supporting environmental investments on both the demand (public procurement of "green" goods) and the supply sides (subsidies and tax incentives) encourages companies to invest longer in "green" economy innovation and producers to benefit from economies of scale. In turn, this can contribute to more sustainable consumption of green goods, leading to a spike in investment.

For example, sustainable public procurement programs for "green" goods in Austria, Denmark, Finland, Germany, the Netherlands, Sweden and the UK have reduced industrial production-related CO2 emissions by an average of 24\% over 2012-2017. [24] Public procurement also contributed to the formation in the EU countries of a segment of the agroindustrial market associated with the movement of "organic" products and drinks, cars with low fuel consumption and furniture made from recycled wood with a total capacity of more than 700 billion euros by 2018 [22]. "Green" subsidies, such as measures to bring to parity prices for "green" and traditional industrial goods and transport services, as well as tax incentives, research grants and guarantees on loans to small businesses, applied in the EU, pursue the following goals [17]:

- taking timely measures to avoid freezing of "green" industrial assets and breaks in supply chains with the loss of valuable natural capital;

- the formation of a "green" innovation infrastructure that provides significant financial or non-financial benefits for private firms (venture and guarantee funds, recruiting and patent services, etc.);

- business incubation of early stage green companies as a part of a strategy to accumulate comparative advantages and stimulate long-term employment and growth;

- incentives to mobilize private capital to expand investments in the green economy (property, emission, financial).

For example, some municipalities in India have introduced property tax rebates for solar water heater users. In some cases, this discount reaches $65 \%$ of property tax. An alternative type of tax incentives used to stimulate the production of energy from renewable sources in China is accelerated depreciation of fixed assets. It allows the investor to quickly reduce the book value of eligible fixed assets and thereby reduce their taxable profit. The introduction of renewable energy technologies has been successfully promoted by price support measures and net metering methods. The most widespread incentive measure in the EU energy sector 
is the use of tariff subsidies to create and improve technologies for generating electricity from renewable sources.

Special mention should be made of the net accounting method to stimulate investment in small-scale energy projects, which are widely used in the United States and based on increasing the benefits from the use of renewable sources. Using this method, the consumer receives a rebate from future electricity bills if the amount of energy entering the national energy system from the consumer's generator, powered by renewable raw materials, exceeds the amount of energy withdrawn by the consumer from the system. Net accounting is widely adopted, in addition to the United States, in Mexico and Thailand. As applied to investments in "green" energy, it increases the attractiveness of investments in alternative power producing specifically for small investors, expanding their circle.

The analysis of subsidies for the production of energy from renewable sources showed that in a situation where the state wants to increase private investment in a particular sector, it is important that support is stable and predictable, gives investors certainty and is canceled in a timely manner to stimulate innovation. For the state, the provision of subsidies in many cases involves significant economic costs. If subsidies are channeled into traditional industrial sectors, then meaningful lower prices of goods lead to environmental inefficiency, large amounts of waste and excessive consumption, resulting in premature scarcity of valuable non-renewable resources and degradation of ecosystems [25].

In 2015, the volume of subsidies for fossil fuel consumption worldwide was estimated by the UN Environment Group at \$ 612 billion. Another \$ 120 billion were subsidies for production [26]. By artificially lowering the cost of using fossil fuels, these subsidies deter consumers and companies from taking energy efficiency measures that would quickly pay off in the absence of these subsidies. Thus, in contrast to "green" subsidies, incentives for traditional energy support a barrier to the development of technologies for the production of energy from renewable sources, which deprives industrialized countries of the opportunity to increase demand for alternative energy by $6.5 \%$ and reduce greenhouse gas emissions by $7.4 \%$ [27].

However, it should be remembered that eliminating subsidies is a difficult macroeconomic task; subsidies are justified by the fact that they benefit poor households. However, when subsidies are misappropriated, the bulk of funding often goes to high-income households; however, abrupt elimination of subsidies inevitably leads to higher prices for subsidized goods.

Therefore, the consensus opinion of economists studying the problems of investing in the "green" economy suggests that subsidies are less effective than tax and market instruments. Tax incentives for environmental investments are aimed at reducing price imbalances between green and traditional resource-intensive goods. Negative externalities such as environmental pollution, deterioration in health or a drop in labor productivity, as a rule, are not reflected in costs, which reduces the attractiveness of switching to "green" goods and services. A similar situation is observed in the field of industrial and domestic waste recycling. Thus, the price for a product made from waste and for a disposal service, as a rule, does not reflect all the costs of waste processing and disposal. The solution to this problem is to include these additional costs in the price of the good or service without increasing the price. To this end, investors in recycling industries should receive corrective tax incentives that preserve the profitability of these industries and their attractiveness to investors.

For example, Singapore, where in the 1980s the world's first toll road system was introduced, today is one of the leaders in the application of pricing tools to address waste disposal and water shortages. For 2009-2018 Singaporean entrepreneurs have attracted more than $\$ 70$ billion in the construction of enterprises for waste recycling and water purification 
[27]. Also, the introduction of pollution charges also stimulates investment in new resourcesaving technologies, as companies begin to develop cleaner and, at the same time, highperformance production facilities. For example, in Sweden, the introduction of a tax on nitrogen oxides emissions in 1999 led to a significant increase in investment in technologies and equipment to reduce emissions. If before the introduction of the tax, it was used by $7 \%$ of companies, then since $2000-62 \%$ of companies engaged in the production, accompanied by emissions of nitrogen oxides [28].

In general, an increasing number of institutional investors, such as pension funds and insurance companies, seek to minimize the risks associated with environmental pollution. For example, the Norwegian Pension Global Fund, a passive investor in the capital of about 8,500 companies (with an average share of $1.4 \%$ ), prioritizes generally accepted ethical values, with the declared priority of environmental protection [29-30]. Therefore, the new investment program of the Global Fund, developed jointly with the Norwegian Ministry of Finance, provides for a $30 \%$ increase in investments in climate-friendly energy, reduction of carbon monoxide emissions, increased availability of clean water in a number of developing countries, and waste recycling.

Thus, environmental investment today ceased to be exclusive prerogative of leading countries, and develops in a system of complex organizational, institutional, financial interactions between states, private and corporate investors, producers and consumers.

\section{Conclusion}

Today we can talk about the global effect of increasing the attractiveness of environmentally friendly investments for a wide range of actors - states, institutional investors, large and small firms. The development of a system for stimulating "green" investments has already passed the stage of declarations at the national and interstate levels, and today is associated with the direct application of indirect regulation (subsidies, tax incentives). This largely determines the expected transition to alternative energy, waste recycling and the widespread introduction of resource-saving technologies, initiated by producers of "green" goods and services, as well as the largest national financial institutions around the world.

\section{References}

1. S. Khouri, H. Pavolová, M. Cehlár, T. Bakalár, Metalurgija 55(3), 500-502 (2016)

2. Š. Kuzevič, Gergel’ová Bindzárová, Ž. Kuzevičová, V.G. Mikhailov, Economics and Innovation Management 3, 9-20 (2020) DOI: 10.26730/2587-5574-2020-3-9-20

3. M. Yazevich, O. Kalinina, O.Zhironkina, E3S Web of Conferences 134, 03004 (2019)

4. V. Trifonov, O. Loyko, D. Nesteruk, S. Zhironkin, E. Strekovtsova, AIP Conference Proceedings 1800, 050009 (2017)

5. S.A. Zhironkin, Ugol' 4, 47-49 (2002)

6. S. Zhironkin, S. Demchenko, G. Kayachev, M. Ryzhkova, O. Zhironkina, E3S Web Conferences 41, 04011 (2018)

7. T.V. Kiseleva, V.G. Mikhailov, Economics and Innovation Management 4, 70-78 (2018) DOI: 10.26730/2587-5574-2018-4-70-78

8. M.S. Egorova, Siberian Science Bulletin 1(11), 474-480 (2011)

9. S. Zhironkin, A. Selyukov, M. Gasanov, Energies 13(13), 3305 (2020) 
10. M. Cehlár, P. Rybár, J. Mihók, J. Engel, Journal of Mining and Geotechnical Engineering 1, 4-31 (2020) doi: 10.26730/2618-7434-2020-1-4-31

11. M. Tyulenev, S. Zhironkin, E. Tyuleneva, A. Abay, S. Anyona, M. Hellmer, Coal International 265(3), 30-34 (2017)

12. E.A. Taran, V.A. Malanina, F. Casati, Economics and Innovation Management 4, 39-46 (2020) DOI: $10.26730 / 2587-5574-2020-4-39-46$

13. E.A. Gasanov, A.E. Zubarev, Economics and Innovation Management 2, 23-29 (2020) DOI: $10.26730 / 2587-5574-2020-2-23-29$

14. M.E. Konovalova, O.Y. Kuzmina, S.A. Zhironkin, Lecture Notes in Networks and Systems 84, 180-188 (2020)

15. S.M. Sukhorukova, A.M. Pogorely, A.V. Samorokov, Economics and Innovation Management 1, 54-65 (2020) DOI: 10.26730/2587-5574-2020-1-54-65

16. Z. Šimková, M. Cehlár, H. Pavolová, M.A. Tyulenev, Economics and Innovation Management 3, 47-58 (2020) DOI: 10.26730/2587-5574-2020-3-47-58

17. Čulková, H. Pavolová, S. Khouri, L.G. Shut’ko, Economics and Innovation Management 3, 77-87 (2020) DOI: 10.26730/2587-5574-2020-3-77-87

18. M.S. Zlotnikov, V.V. Telnykh, S.I. Mutovin, S.K. Demchenko, J.J. Suslova, Journal of Environmental Management and Tourism 8(2), 366-372 (2017)

19. S.M. Sukhorukova, A.M. Pogorely, A.V. Samorokov, Economics and Innovation Management 2, 45-53 (2020) DOI: 10.26730/2587-5574-2020-2-45-53

20. M. Beer, R. Rybár, M. Cehlár, S. Zhironkin, P. Sivák, Energies 13(10), 2450 (2020)

21. P. Sivák, P. Tauš, R. Rybár, M. Beer, Z. Simkova, F. Banik, S., Zhironkin, J. Citbajová, Energies 13(15), 3878 (2020)

22. A.G. Koryakov, M.V. Kulikov, Economics and Innovation Management 4, 16-26 (2018) DOI: 10.26730/2587-5574-2018-4-16-26

23. A.V. Myaskov, S.M. Popov, Economics and Innovation Management 1, 16-24 (2018) DOI: 10.26730/2587-5574-2018-1-16-24

24. D.A. Shchedrova, V.T. Borisovich, Y.A. Leonidova, Economics and Innovation Management 2, 37-43 (2018) DOI: 10.26730/2587-5574-2018-2-70-76

25. A.N. Tokarev, Economics and Innovation Management 1, 25-35 (2018) DOI: 10.26730/2587-5574-2018-1-25-35

26. UN. Green Economy Developing Countries Success Stories, 2010. URL: http://www.un.org/ru/ga/unep/

27. M. Tyulenev, E. Garina, A. Khoreshok, O. Litvin, Y. Litvin, E. Maliukhina, IOP Conference Series: Earth and Environmental Science 50(1), 012035 (2017)

28. WHO, UNICEF. Sanitation and Drinking Water. URL: http://www.who.int/mediacentre/news/releases/2010/ water_20100315/ru/index.html

29. O.E. Kalenov, S.N. Kukushkin, Economics and Innovation Management 3, 88-96 (2020) DOI: 10.26730/2587-5574-2020-3-88-96

30. E.Y. Dotsenko, N.P. Ezdina, A.S. Khasanova, M.I. Khasanov, E3S Web of Conferences 247, 01068 (2021) 